Cambridge Journal of Economics, Volume 34, Number 6, 15 November, 2010, Pages 1075-1096

\title{
Board Structure and Executive Pay: Evidence from the UK
}

\begin{abstract}
We examine the impact of board structure on executive pay for 1,880 UK public firms over 1983-2002, using panel data analysis. Firstly, the proportion of non-executive directors tends to decrease the rate of increase in executive pay whilst board size tends to increase it. Secondly, the proportion of non-executives strengthens the relation between the rate of increase in executive pay and changes in performance. In particular, although for firms in general the pay-performance link is much weaker when performance is poor, a higher proportion of non-executives strengthens this link considerably. Finally, firms that increase the number of non-executives in order to comply with the Cadbury Code of 1992, experience both a decline in the rate of increase in executive pay and an increase in pay-performance sensitivity.
\end{abstract}

JEL classification: G32, G34

Keywords: Executive pay; Board size; Board composition; UK; Cadbury 


\section{Introduction}

Over the past two decades, the growth in executive pay levels and the perceived lack of its link to firm performance has received significant attention. It is the board of directors' responsibility for setting executive pay, and their perceived inability to do so effectively has been one of the drivers for corporate governance reforms around the world, along with other perceived failures resulting in corporate scandals and failures. Such reforms have included demands for smaller boards with a higher proportion of independent directors, the belief being that such boards will be more effective at monitoring tasks which include limiting excessive pay awards and providing a stronger pay-performance link.

Despite the importance of this issue, there is only limited empirical evidence relating executive pay to board structure. The small number of previous studies nearly all use US data, employ relatively small selective samples and use a cross-sectional econometric approach. This paper contributes to the literature by examining the impact of board structure on executive cash compensation in the UK. In contrast to previous studies, we employ a very large comprehensive panel dataset of some 1,880 firms over a long time period, 1983-2002. Our results should therefore be more robust to sample selection and time period bias. Providing evidence from outside the US is of interest to see whether and how the relation between board structure and pay differs in a different setting, with a different legal and institutional environment. Although the UK corporate governance system has many similarities to that of the US, there are notable differences (discussed in Section 3 below) which may undermine the monitoring role of non-executive directors.

We find evidence that non-executive directors play an important monitoring role in shaping both the rate of increase in executive pay levels and the relation between the rate of increase in executive pay levels and changes in performance. Firstly, the proportion of nonexecutives tends to decrease the rate of increase in executive pay levels whilst board size tends to increase it. Secondly, the proportion of non-executives strengthens the relation 
between the rate of increase in executive pay levels and changes in performance. We find evidence of an asymmetric pay-performance sensitivity for all firms, whereby when performance is poor, the pay-performance link is much weaker than when performance is strong. However, a higher proportion of non-executives strengthens the link between pay and performance when performance is poor. In contrast, board size has little impact on the payperformance link.

Analysis of the UK over the sample time period allows us to address the impact of the Cadbury Report (1992) on executive pay. This corporate governance reform (described in Section 3 below), motivated by perceived corporate governance failures including excessive pay levels, recommended that all listed firms should (among other things) have at least three non-executive directors. Adoption of the recommendations was on a 'comply or explain' basis. Previous studies have found that adoption of Cadbury leads to a stronger link between firm underperformance and CEO dismissal (Dahya et al., 2002), a greater likelihood of appointing an outside CEO (Dahya et al., 2005), and better overall performance (Dahya and McConnell, 2007). Our results add to this literature by showing that adopting firms also experience a lower rate of increase in executive pay levels and an increase in payperformance sensitivity.

Our long sample period allows us to address problems of endogeneity. Firstly, we employ panel data fixed effects methods that control for the possibility that both board structure and executive pay are determined by some unobservable firm specific variable. Secondly, our analysis of the Cadbury Reforms can to some extent address the concern that board structure and executive pay are jointly determined by one another. ${ }^{1}$ To the extent that board structure changes following Cadbury can be attributed to Cadbury then they are exogenous (Dahya et al., 2002; and Chhaochharia and Grinstein, 2009). However, it is important to note that since the Cadbury recommendations were not compulsory, Cadbury is not a strictly exogenous event, unlike Sarbanes-Oxley which was compulsory by US law. 
The paper proceeds as follows: Section 2 provides a review of the literature on board structure and executive pay. Section 3 describes aspects of board structure and executive pay in the specific UK context. Section 4 describes the methodology and data. Section 5 presents the empirical results. Section 6 concludes.

\section{Board Structure and Executive Pay: Literature Review}

One of the primary functions of boards of directors is to monitor managers, which includes setting executive pay. As Jensen and Murphy (2004, p. 50) note; "A primary role of boards of directors is to hire, fire, and set the remuneration of the CEO and other top executives". Principal-agent theory shows how pay should be determined by performance in a way that ensures managers pursue the interests of shareholders (Murphy, 1999). However, there is a general perception that executive pay is often too high, whilst the large empirical literature shows that the pay-performance relationship is small and weak (Murphy, 1999). It has therefore been argued that executive pay is possibly a symptom of the principal agent problem rather than being an answer to it, and is manipulated by CEOs who are monitored ineffectively by their boards (Bebchuk and Fried, 2003). Two characteristics of boards that are argued to be of crucial importance in providing the monitoring function and in setting effective executive pay, are the proportion of non-executive directors and board size.

The proportion of non-executive directors on the board is argued to have a restraining impact on pay levels and a positive impact on the pay-performance link. Fama and Jensen (1983) argue that compensation decisions should be carried out by non-executive directors, who are more likely to be independent of the CEO and objective when it comes to evaluating the CEOs performance. Also, non-executive directors often already have experience in monitoring top management and may wish to signal their ability to other firms that may subsequently employ them as non-executives. In contrast, "insider-dominated boards imply problematic self monitoring, and particularly weak monitoring of the CEO, since the CEO is likely to be in a position to influence the insider directors career advancement within the 
firm" (Zajac and Westphal, 1994, p. 125). Recent regulation is in line with these arguments. Stock exchange regulation changes made following the Sarbanes-Oxley Act 2002 requires US listed firms to have a majority of independent directors on the board, one aim of which is to reduce the manager's influence over executive pay.

The impartiality and objectiveness of non-executive directors described above is not universally accepted. Non-executive directors are frequently not independent of the CEO, who may have been responsible for their selection. Hermalin and Weisbach (1988) find that board composition is determined by the CEO. The CEO could be friends with non-executive directors, and may also provide consulting work to them (Singh and Harianto, 1989). Furthermore, if non-executive directors are also executive directors at other companies, awarding high pay as non-executives can potentially result in them receiving higher pay as executives because of the tendency to base pay levels on levels in comparable firms. Hence there is a potential conflict of interests here (Main and Crystal, 1988; Ezzamel and Watson, 2002).

The main findings from previous empirical studies on board structure and executive compensation are displayed in Table 1 below. Overall, the proportion of non-executives appears to be positively correlated with higher executive pay. All ten previous studies find a positive correlation, six of which are statistically significant (Main, 1991; Main and Johnston, 1993; Cosh and Hughes, 1997; Cyert et al., 2002; Fernandes, 2008; and Ozkan, 2007), and four of which are insignificantly positive (Mangel and Singh, 1993; Angbazo and Narayanan, 1997; Kren and Kerr, 1997; and Evans and Evans, 2002). Only two studies have examined the impact on pay-performance sensitivity. Kren and Kerr (1997) find a negative impact where performance is measured using share returns. However, this result is not robust, being of marginal statistical significance and not holding when performance is measured using profitability. In contrast, Conyon and Peck (1998) employ a fixed effects methodology and find a positive relation (using share returns). Therefore, previous findings on non-executive proportion and pay-performance sensitivity are mixed. 


\section{TABLE 1 HERE}

Smaller board size is argued to have a restraining impact on pay levels or changes and a positive impact on the pay-performance link. Smaller boards are expected to be more effective at setting executive pay than larger boards because the latter suffer from coordination costs and free rider problems (Yermack, 1996). For example, with larger boards it is more difficult to arrange meetings, reach agreement, which leads to slower and lessefficient decision-making (Jensen 1993). Free-riding increases because the cost to an individual director of not carrying out his monitoring role properly decreases as board size increases (Lipton and Lorsch, 1992). Jensen (1993) and Lipton and Lorsch (1992) suggest that as board size increases beyond a certain point, these problems outweigh the initial advantages from having more directors to draw on, which leads to less effective boards. ${ }^{2}$

The main findings from previous studies on board size and executive compensation are also displayed in Table 1. Overall, board size appears to have a positive impact on pay levels. Five of the six studies find a positive impact (Main, 1991; Angbazo and Narayanan, 1997; Hallock, 1997; Core et al., 1999; and Ozkan, 2007), and of these, only Angbazo and Narayanan (1997) do not find a significant impact. Only the study by Cyert et al. (2002) does not find a positive impact, although it is worth noting that this study does find a positive impact on the bonus element of compensation, if not the base salary. In terms of the impact of board size on pay-performance sensitivity, only Yermack (2006) examines this and finds that the sensitivity of CEO cash compensation (salary and annual bonus) to share returns is weaker for firms with larger boards.

One criticism of the above studies is that board size and structure are endogenous variables, jointly determined by one another or by some unobservable firm characteristic which, in turn determine CEO compensation (Hermalin and Weisbach, 2003). In order to address this problem, Chhaochharia and Grinstein (2009) argue that examination of a regulatory change helps mitigate the endogeneity problem, since changes to board structure can be attributed to the exogenous change (see also Dahya et al., 2002). Chhaochharia and 
Grinstein (2009) consequently use the changes made by the Sarbanes-Oxley Act and associated changes to stock exchange regulations ${ }^{3}$ to study the effect of board structure on CEO compensation. They find that for those firms impacted by the changes, executive pay decreases by $10-25 \%$, and that the one provision of the rules that has a significant impact is the requirement for a majority of independent directors on the board.

\section{Board Structure and Executive Pay: The UK Context}

The UK provides an interesting environment in which to study the effect of board structure on executive pay. The UK corporate governance system has many similarities to that of the US including a common law system and unitary board structures. However, there are notable differences in terms of the role of non-executive directors and executive pay.

The prescribed advisory and monitoring functions of UK non-executive directors are very similar to those in the US (Cadbury, 1992). However, there are several reasons why the monitoring function may possibly be carried out less effectively in the UK. Firstly, UK nonexecutive directors are rarely held legally accountable for failing to fulfill their legal duty of care and loyalty, in contrast to the US where it is much easier to sue a director through a civil action than it is in the UK. The lower threat of legal action in the UK could result in less incentive to monitor (Franks et al., 2001). Secondly, UK boards have historically consisted of a lower proportion of non-executive directors who are less independent from management (e.g., Cosh and Hughes, 1987). ${ }^{4}$ Thirdly, the financial incentives (shareholding and remuneration) for non-executive directors in the UK to fulfill their functions are lower (Cosh and Hughes, 1987; and Higgs, 2003). The relative strength of other substitute governance mechanisms is also stronger in the UK and this further weakens the monitoring role played by non-executive directors (Agrawal and Knoeber, 1996). For example, UK companies have less available takeover defences and consequently the market for corporate control should perform a stronger function (Short and Keasey, 1999). Additionally, British institutional investors are more active monitors, able to act collectively (Crespi-Cladera and Renneboog, 2003), and 
expected to perform a stronger role because ownership concentration is higher (Short and Keasey, 1999).

Consistent with this argument, UK evidence suggests that non-executives do not play a strong monitoring role in terms of CEO turnover (Cosh and Hughes, 1997; and Franks et al., 2001) or in terms of improving firm performance more generally (see e.g., Vafeas and Theodorou, 1998). ${ }^{5}$ In contrast, although the US empirical evidence, reviewed by Hermalin and Weisbach (2003), shows no association between the proportion of non-executive directors and general firm performance, it does show a positive relation with regard to specific firm actions such as acquisitions and CEO turnover decisions. Finally, in contrast to US findings, UK board structure is not determined by factors associated with monitoring costs and benefits (Guest, 2008).

In terms of executive pay, there are several notable differences. Firstly, Conyon and Murphy (2000) show that US pay levels, in terms of base salary, bonus, and long term incentives are much higher than in the UK. Secondly, US companies have a much higher proportion of bonus to total compensation, and of long term incentives to total compensation. Share option grants account for only $10 \%$ of pay in the UK compared to $50 \%$ in the US. Share option grants declined in the UK over the 1990s and, for most of the period under consideration were linked to base salary and so were not an independent element of salary. Thirdly, the level of reporting of executive pay in the UK has until recently been lower than in the US. Until 1997, the principal disclosure requirement demanded that firms disclose only the cash compensation (pay plus bonus plus benefits) of the Chairman, the highest paid director, and the entire board whilst information on share options or long-term incentive plans was not available.

Starting in the 1990s, a series of corporate governance reforms were introduced in the UK that had a significant impact on board structure. The Cadbury Report in 1992 made several recommendations to enhance the effectiveness of non-executive directors as monitors. The Report was motivated by perceived corporate governance failures resulting in corporate 
scandals, failures, and excessive pay levels which appeared unrelated to performance. ${ }^{6}$ One key recommendation was that all listed firms should have at least three non-executive directors. ${ }^{7}$ The number of non-executive directors increased significantly following Cadbury. Dahya et al. (2002) report that in 1998, 62.3\% of all London Stock Exchange listed companies had at least three non-executive directors, in contrast to only $26.7 \%$ in 1988 . Subsequently, the Hampel Report (1998) required that at least one third of the board be nonexecutives and the Higgs Report (2003) required that at least 50\% be non-executives.

With specific regard to executive pay, Cadbury did not recommend lowering pay levels or pay growth. The report did however recommend that directors' pay should be determined by a remuneration committee, wholly or mainly comprised of non-executive directors and chaired by a non-executive. The Greenbury Report (1995) subsequently recommended that the remuneration committee should consist entirely of non-executives. The anticipation was that shareholder and manager interests would be aligned more closely and so link pay more directly to performance. However, there is little empirical evidence to support this. Conyon (1997) and Benito and Conyon (1999) find that the presence of a remuneration Committee does not have a significant effect on either pay levels or the pay-performance link. The Greenbury Report (1995), which focused solely on executive pay, recommended that firms disclose details for all elements of pay for all executive directors and hence greatly increased disclosure from 1997 onwards.

It is important to note that adoption of these recommendations (Cadbury, Greenbury, Hampel, and Higgs), which now form part of the Combined Code on Corporate Governance (2006), has not been mandatory. They were, and are, a 'comply or explain' recommendation. ${ }^{8}$

\section{Methodology and Data}

To test for the existence of a relationship between executive pay and board size and structure we build on a basic relationship between executive pay and the various determinants 
which have been identified as important in the literature on executive pay (see e.g., Girma et al., 2006). This basic relationship may be written as follows:

$$
\begin{aligned}
\text { Pay }_{i t}=\beta_{0} & +\beta_{1} \text { Pay }_{i t-1}+\beta_{2} \text { Size }_{i t}+\beta_{3} \text { Return }_{i t}+\beta_{4} \text { Standard deviation }_{i t} \\
& +\beta_{5} \% \text { Non-executives }_{i t-1}+\beta_{6} \text { Board size }_{i t-1}+h_{t}+f_{i}+e_{i t}
\end{aligned}
$$

where $P a y_{i t}$ is defined as the logarithm of total cash compensation (salary plus bonus plus the cash equivalents of any perquisites but excluding pension contributions) of the highest paid director in company $i$ at time $t$. In using this measure of executive pay, we follow other UK executive pay work (see e.g., Conyon, 1997; Conyon and Peck, 1998; Girma et al., 2006, and Girma et al., 2007). Until 1997, this was the only widely available measure of CEO pay in the UK. Although it has been possible since 1997 to identify the specific components of compensation (such as share options) received by each board member, our econometric model requires two years of lagged compensation and hence any analysis involving this more recent data would be restricted to years 1999-2002 only. Hence for almost all our sample period, our pay measure is the only one available and subsequently the only measure employed. We expect at most a minimal bias by not examining long term incentives since over the sample period such incentives were not an independent element of salary and formed only a small part of executive compensation.

Pay ${ }_{i t-1}$ is the lagged value of variable $P a y_{i t}$. The impact coefficient $\beta_{1}$ gives an estimate of the degree of top pay persistence. Previous studies have shown that there is significant persistence in top pay (Conyon, 1997; and Girma et al., 2006) and therefore prior pay needs to be controlled for. Size it represents the logarithm of firm sales and is our measure of company size. Return is the logarithm of the buy and hold share return over the 12 months preceding the financial year end. Standard deviation ${ }_{i t}$ is the standard deviation of monthly share returns over the 12 months preceding the financial year end. \%Non-executives is the number of non-executive directors divided by the total number of (executive and nonexecutive) directors on the board. Non-executive directors are part-time directors, whilst executive directors are employed full time and are involved in the day to day running of the 
company in addition to their director's duties. Board size is the logarithm of the total number of (executive and non-executive) directors on the board. ${ }^{9}$ We employ the lags of board structure since the components of cash compensation (base salary level and bonus policy), tend to be determined at the start of the financial year (see e.g., Benito and Conyon, 1999). $h$ ${ }_{t}$ are year dummies employed to account for economy-wide impacts, and $e_{i t}$ is an error term.

$f_{i}$ are firm specific dummy variables. Both executive pay and board structure could be jointly determined by an unobservable time invariant firm specific variable, which could bias the relation between the two. One way to address this problem is with a fixed effects model, where firm specific dummy variables are included to remove all firm specific unobservable effects. However, the presence of the lagged dependent variable Pay ${ }_{i t-1}$ in a fixed effect model means that the conventional fixed effects estimator is biased (Nickell, 1981). To overcome this problem, we instead take first differences of equation (1) to eliminate the company specific fixed effects (following Anderson and Hsaio (1982)) as follows:

$$
\begin{aligned}
\Delta \text { Pay }_{i t}= & \beta_{0}+\beta_{1} \Delta \text { Pay }_{i t-1}+\beta_{2} \Delta \text { Size }_{i t}+\beta_{3} \Delta \text { Return }_{i t}+\beta_{4} \Delta \text { Standard deviation }_{i t} \\
& +\beta_{5} \Delta \% \text { Non-executives }_{i t-1}+\beta_{6} \Delta \text { Board size }_{i t-1}+h_{t}+e_{i t}
\end{aligned}
$$

where the operator $\Delta$ on any variable $\mathrm{X}$ is simply current value $\mathrm{X}$ minus last period value ( $\Delta$ $\left.\mathrm{X}=\mathrm{X}_{t}-\mathrm{X}_{t-1}\right)$. By taking first differences of the natural logarithm of pay we therefore examine the rate of increase in pay (see e.g., Girma et al., 2006).

Taking first differences as in equation (2) introduces an MA(1) error term, and therefore estimation by ordinary least squares results in biased estimates on the lagged dependent variable, $\beta_{1}$ (Nickell, 1981). To avoid this problem, we use instrumental variable techniques to estimate $\Delta P a y_{i t-1}$. We estimate the model using the Arrellano and Bond (1991) generalised method of moments procedure, which uses lagged levels of all variables from period ( $\mathrm{t}-2)$ data and earlier as valid instruments in the first differences model. This yields valid instrumental variable estimates in the absence of second-order serial correlation, and has been used by previous empirical pay studies (see e.g., Main et al., 1996; Conyon, 1997; and Girma et al., 2006). The validity of the instruments used is examined using the Sargan test of 
instrument validity, and the model's success in removing the second order serial correlation is examined using a test for second order serial correlation.

The source of data for our sample of UK publicly quoted firms is Datastream, from which all company board and performance variables are collected. We restrict our sample to those Datastream firm years in which data is available on all the above variables. Three successive years of data are required because the regression model described in equation (2) requires two years of lagged data. It was therefore necessary to exclude from the Datastream population of UK public firms those firms lacking three continuous years of data over the period 19812002. Our pay model is estimated from 1983 to 2002, but for 1983 observations we require data going back to 1981. We exclude financial and property companies (Datastream Level 4 Industries 80-89), due to the specific characteristics of financial ratios in these industries. Our final sample consists of an unbalanced panel of 1,880 companies between 1983 and 2002 for which we have 13,492 firm year observations. The balance of the panel is shown in Table 2 below.

\section{TABLE 2 HERE}

Table 3 below presents the summary statistics for the variables used in the regression analysis. All the absolute variables are converted to 2002 sterling values using the UK Retail Price Index, and all variables are winsorized at the $1^{\text {st }}$ and $99^{\text {th }}$ percentiles to remove influential outliers. The average (median) proportion of non-executive directors for our sample is 0.43 (0.43), which is similar to previous UK studies (e.g., Cosh and Hughes, 1987) but much smaller than that reported for US studies. For example Linck et al. (2007) report an average proportion of non-executive directors of 0.66 . The average (median) board size is 7 (7), which is identical to the average board size of 7 reported by Linck et al. (2007) for a comprehensive US study.

TABLE 3 HERE 


\section{Empirical Results}

\subsection{Impact of board structure on changes in pay}

Column (1) of Table 4 below reports the results of estimating equation (2). The coefficient for the lagged rate of increase in pay is significantly positive, indicating that the rate of increase in pay is positively related to its lagged value. The coefficient for firm size is significantly positive, confirming that executive pay is positively impacted by firm size. The coefficient for change in share return is significantly positive, indicating that there is a significant link between pay and performance in the UK. The sign and magnitude of these estimated coefficients are in line with the previous evidence of Girma et al. (2006) for the UK. The coefficient for lagged pay (0.30) is larger, than that for size $(0.14)$, which is in turn greater than that for performance (0.05). The latter difference indicates that, although performance has a positive impact on pay, firm size has a relatively larger impact. The coefficient for the standard deviation of share returns is significantly negative. The diagnostics for the instrument set are adequate since both the Sargan $p$-value and the $2^{\text {nd }}$ order serial correlation $p$-value are insignificant ( $p$-values of 0.46 and 0.16 respectively)

\section{TABLE 4 HERE}

The regression estimates show a significantly inverse association between the rate of increase in pay and the change in the proportion of non-executives. The coefficient is -0.12 which is statistically significant at the one percent level. It is also economically important, implying that an increase in the proportion of non-executives from 0.5 to 0.75 will reduce the rate of increase in pay by roughly three percent. This finding stands in contrast to the previous studies described above, all of which find a positive relation, and it is important to understand why our results differ so significantly. In additional tests we find that the results clearly differ because of the econometric methodology employed. Previous studies do not employ a fixed effect model nor control for prior pay levels. When we employ an ordinary least squares model in levels and do not control for prior pay levels, the coefficient for the proportion of 
non-executives is significantly positive, consistent with previous studies. When we add lagged pay to this regression, the coefficient is statistically insignificant. When we additionally include firm fixed effects, the coefficient is significantly negative. Indeed, the coefficient is significantly negative in the fixed effect model, even when lagged pay is excluded. Clearly, the methodology employed has a critical impact on the conclusion drawn. We believe that it is critical to control for both fixed effects and for lagged pay. The fact that previous board structure-pay studies do not do so means that the conclusion one draws from these previous studies could be a spurious one. Instead, our findings suggest that the change in the proportion of non-executives exerts a negative influence on the rate of increase in pay which is consistent with the idea that non-executives play an important monitoring role in restraining excessive pay growth.

The regression estimates show a positive and significant association between the rate of increase in pay and the change in board size. This is consistent with the argument that coordination, communication, and free riding problems restrict the board's ability to restrain excessive pay awards when board size increases. This is consistent with all previous studies and is robust to the different regression methods described above.

\subsection{Impact of board structure on the pay-performance relation}

In order to examine the impact of board structure on the pay-performance link, we include interactive variables that are equal to the proportion of non-executives multiplied by the share return (\%Non-executives ${ }_{i t-1} *$ Return $\left._{i t}\right)$, and board size multiplied by share return (Board size ${ }_{i t-1}^{*}$ Return $_{i t}$ ). The results are reported in Column (2) of Table 4 above. The coefficient for the proportion of non-executives multiplied by the share return variable is significantly positive at the one percent level. This indicates that an increase in the proportion of nonexecutives leads to a stronger pay-performance link, and is consistent with the one previous UK study in this area (Conyon and Peck, 1998). The coefficient for the board size multiplied by share return variable is positive and marginally statistically significant at the ten percent 
level. This latter finding runs contrary to our expectations, since it suggests that larger boards are associated with a stronger pay-performance link.

We test the robustness of these results by employing additional interactive variables. Previous studies have shown that when estimating pay-performance sensitivities, it is important to control for the variance of firm share returns and firm size. Aggarwal and Samwick (1999) show that pay-performance sensitivity is higher for firms with high share return variance, whilst Schaefer (1998) shows that it is weaker for large firms. It is important to control for such factors because board size and the proportion of non-executives are negatively impacted by share return variance and positively impacted by firm size, respectively (see e.g., Linck et al., 2007). In Column (3) we report results including two additional interactive variables; standard deviation of share returns multiplied by share return $\left(\right.$ Standard deviation $_{i t} *$ Return $\left._{i t}\right)$, and firm size multiplied by share return $\left(\right.$ Size $_{i t} *$ Return $\left._{i t}\right)$. The coefficient for the former variable is significantly negative, consistent with Aggarwal and Samwick (1999). The coefficient for the latter variable is significantly positive, suggesting that larger UK firms have a stronger pay-performance link, contrary to Schaefer's (1998) findings for the US. In this regression, the coefficient for the proportion of non-executives multiplied by the share return variable is still significantly positive. However, the coefficient for the board size multiplied by the share return variable is now statistically insignificant. It appears that once we control for size and variance impacts on the pay-performance link, board size has no additional impact. Our results do not therefore support the argument that board size has a negative impact on the pay-performance relation, as found by Yermack (1996).

We examine whether our results differ over different ranges of board size and proportion of non-executives. The results, not tabulated, show that the positive effect of changes in board size on the rate of increase in pay appears to hold at even very small levels of board size. Unlike Yermack (1996), a sizeable minority (22 percent) of our sample observations have board size below six (the minimum board size is three directors). The coefficient for board 
size for this subsample is 0.072 ( $p$-value of 0.038 ), which is in fact greater than the coefficient for the sample of firms with board size greater than or equal to six (coefficient of $0.041, p$ value of 0.026). This is consistent with Eisenberg et al. (1998) who find that a negative association between board size and firm performance exists even over the lowest range of board sizes. Similarly, the impact of board size on the pay-performance link is very similar for firms with board sizes less than six and those with board sizes greater than or equal to six. With regard to the proportion of non-executives, when this is less than the median of 0.43 , the coefficient for change in proportion of non-executives is -0.018 and statistically insignificant. In contrast, when the proportion of non-executives is greater than 0.43 , the coefficient is equal to -0.178 and significant at the one percent level. Therefore, increases in the proportion of non-executives are associated with greater impacts when the proportion is greater. This is consistent with the argument that a minority of non-executives does not have significant monitoring strength, regardless of whether it is a small or large minority. In terms of the payperformance link we find similar evidence. When the proportion of non-executives is greater than the median of 0.43 , the coefficient for the proportion of non-executives multiplied by the share return variable is 0.304 . In contrast, when less than 0.43 , the coefficient is half the size (0.169). However, both coefficients are statistically significant and the difference is not as pronounced as it is for the rate of increase in pay.

\subsection{Impact of board structure on the asymmetric pay-performance relation}

Garvey and Milbourn (2006) show that executive pay does not adjust symmetrically to good and bad performance. In particular, there is an asymmetric pay-performance sensitivity, whereby when performance is poor, the pay-performance link is weaker than when performance is strong. We examine whether this is the case for our sample firms, and if so, whether this asymmetric sensitivity is impacted by board size and structure. In order to examine this we employ two new variables instead of the continuous share return as previously. Return negative ${ }_{i t}$ is equal to the logarithm of the buy and hold share return over the 12 months preceding the financial year end if the raw return is negative, otherwise it is set 
equal to zero. Alternatively, Return positive ${ }_{i t}$ is equal to the logarithm of the return if the raw return is positive, otherwise it is zero. If there is asymmetric pay-performance sensitivity, then the coefficient for the negative return should be lower than that for the positive return variable.

The results are shown in Column (1) of Table 5 below. The coefficients for both variables are positive and statistically significant. However, the coefficient for the negative return variable (0.03) is significantly lower than the coefficient for the positive return variable (0.07). The difference between the two coefficients is statistically significant at the one percent level, showing that pay is more responsive to performance when performance is high than when it is low, consistent with the US evidence of Garvey and Milbourn (2006).

\section{TABLE 5 HERE}

In order to examine whether the asymmetric pay-performance relation differs according to the proportion of non-executives and board size, we include interactive variables as in Table 4, whereby the interaction is with the negative and positive share return variables, rather than the continuous share return. \%Non-executives it-1 * Return negative it, is equal to the proportion of non-executives multiplied by the negative share return variable, whilst $\%$ Nonexecutives $_{i t-1} *$ Return positive $_{i t}$, is equal to the proportion of non-executives multiplied by the positive share return variable. If a higher proportion of non-executives causes a stronger link between pay and performance when performance is poor, then the coefficient for \%Nonexecutives $_{i t-1} *$ Return negative $_{i t}$ will be significantly positive. Analogous arguments apply to the interaction of board size and the negative and positive share return variables.

The results are reported in Column (2) of Table 5. The coefficient for the proportion of non-executives multiplied by the negative return variable is significantly positive, thus a higher proportion of non-executives greatly strengthens the link between pay and performance when performance is poor. In contrast, the proportion of non-executives multiplied by the positive return variable is statistically insignificant. Therefore, the positive relation between pay and performance that occurs when performance is good is not impacted 
by the proportion of non-executives. The coefficient for board size multiplied by the negative return variable is insignificant. However, the coefficient for board size multiplied by the positive return variable is significantly positive, suggesting that larger board size leads to a stronger pay performance link when performance is good.

In order to check the robustness of these findings we again allow, as in Table 4, for the impact of the variance of share returns and firm size on the asymmetric pay-performance relation. In particular, in Column (3) of Table 5 we include four additional interactive variables, Standard deviation ${ }_{i t}$ * Return negative ${ }_{i t}$, Standard deviation ${ }_{i t} *$ Return positive ${ }_{i t}$, Size ${ }_{i t} *$ Return negative ${ }_{i t}$, and Size ${ }_{i t} *$ Return positive ${ }_{i t}$. Standard deviation ${ }_{i t} *$ Return negative ${ }_{i t}$ is equal to the standard deviation of share returns multiplied by the negative share return variable, and so on. The results show that the standard deviation of share returns significantly reduces the pay-performance relation for both negative and positive share returns. However, the firm size multiplied by negative return variable is significantly positive. Hence larger firms have a stronger relation between pay and performance when the latter is poor, compared to small firms. More importantly, once these additional influences are included, the proportion of non-executives still has a significantly positive effect on the payperformance link when performance is poor. However, board size no longer has a positive impact on the pay-performance link when performance is high. ${ }^{10}$

\section{$5.4 \quad$ Impact of board structure reforms on executive pay}

In this section we examine the impact on the rate of increase in pay and pay-performance sensitivity of those firms that adopt the Cadbury recommendation to employ at least three non-executive directors. Of our sample of 1,880 firms, 1,046 have data observations both before and after the introduction of the Code (30/06/1993). Table 6 below provides a breakdown of these 1,046 firms according to whether, for the pre- and post-Cadbury period, they are either always in compliance ('Always'), never in compliance ('Never'), or in and out of compliance ('Some'). The 'Some' category is further broken down (for the post-Cadbury period) according to whether, if there is compliance, it is followed by continual compliance 
('Once comply - always comply'), or by non-compliance ('Comply - then no comply'). We focus on those firms that change their board structure to adopt the Cadbury recommendation. The final row of Table 6 classifies 402 such firms as 'Adopters', since pre-Cadbury they are either never in compliance or not always in compliance, and post-Cadbury they move to continual compliance. The other 644 firms are referred to as 'Non-adopters', since they are either always in compliance, never in compliance, or they comply irregularly.

\section{TABLE 6 HERE}

We employ a dummy variable, Adopters post-Cadbury ${ }_{i t}$, which is set equal to one for all years after which adopting firms adopt Cadbury, zero for all years prior to this. This variable measures the impact of Cadbury adoption on the rate of increase in pay. Secondly, we interact this dummy variable with the firm share return, Adopters post-Cadbury ${ }_{i t} * \Delta$ Return $_{i t}$, to examine whether the pay-performance relation is strengthened following adoption. If so, then the coefficient for this variable should be positive. Firstly, we examine the 402 adopters in isolation. The results are reported in Column (1) of Table 7 below. The coefficient for the post-Cadbury variable is negative but statistically insignificant. The coefficient for the postCadbury variable multiplied by share return is positive and marginally significant at the ten percent level, providing some evidence that adopting firms increase their pay-performance sensitivity following Cadbury.

\section{TABLE 7 HERE}

The specification in Column (1) of Table 7 does not control for general changes in either the rate of increase in pay or the pay-performance relation following Cadbury that may affect all firms. To address this, we include all 1,046 firms in the regression and we include four additional variables. Post-Cadbury it is a dummy variable set equal to one for all financial years ending after Cadbury (31/06/1993), zero for all financial years prior. Post-Cadbury ${ }_{i t}$ *

$\Delta$ Return $_{i t}$ is an interactive variable set equal to the change in firm share return if the postCadbury variable is equal to one, zero otherwise. The former variable will measure the overall impact of Cadbury on the rate of increase in pay whilst the latter will measure the 
impact on pay-performance sensitivity, in both cases for all 1,046 firms. In order to control for the fact that adopters may have either abnormal rates of increase in pay or payperformance regardless of Cadbury, relative to other firms, we employ two further variables. Adopters $_{i}$ is a dummy variable set equal to one for adopters, zero otherwise. Adopters ${ }_{i} * \Delta$ Return $_{i t}$, is an interactive variable equal to whether the firm is an adopter multiplied by the change in firm share return. The results are reported in Column (2) of Table 7.

The dummy variable for adopters post-Cadbury is negative and marginally significant at the ten percent level, providing evidence that the rate of increase in pay of adopting firms is lower following Cadbury that it is beforehand. The interactive variable set equal to the change in share return for adopting firms in post-Cadbury years is again significantly positive, indicating that the pay-performance of adopting firms is higher following Cadbury than before Cadbury. There is no evidence that adopting firms as a whole differ from other firms in terms of either rates of increase in pay or pay-performance sensitivity, since the coefficients for both the dummy variable set equal to one for adopters and the interactive variable set equal to the change in share return for adopters are both statistically insignificant. The dummy variable set equal to one for all firms for post-Cadbury years is insignificantly positive. The interactive variable set equal to the change in the share return for all firms for post-Cadbury years is significantly negative, suggesting that Cadbury actually reduces the pay-performance relation. In order to examine this finding further, in Column (3) of Table 7 we consider the impact of Cadbury on all firms without distinguishing between adopters and non-adopters. In this case the coefficient for post-Cadbury years is again insignificantly positive, whilst the coefficient for the interactive share return variable is still significantly negative, albeit at the ten percent level.

In summary, the results in this section show that firms which adopt the Cadbury recommendation to employ at least three non-executives experience a subsequent decrease in the rate of increase in pay and an increase in pay-performance sensitivity. This suggests that our earlier findings on the impact of non-executive proportion on the rate of increase in pay 
and the pay-performance relation are less likely to be driven by endogeneity since the changes following Cadbury can be assumed to be exogenous to some extent. The finding is also consistent with Chhaochharia and Grinstein (2009) who show that US firms which complied with the stock exchange requirement (introduced following the Sarbanes-Oxley Act) for a majority of independent directors on boards subsequently reduced executive pay levels. However, it is important to note that (unlike Sarbanes-Oxley in the US which was compulsory by law) since the Cadbury recommendations were not compulsory, Cadbury is not exogenous to the same extent. ${ }^{11}$ Despite the positive change for the minority of firms that adopt Cadbury, our results for the overall sample show that Cadbury is associated with a small insignificant increase in the rate of increase in pay and a decrease in pay-performance sensitivity. These findings are broadly consistent with those of Girma et al. (2007), who find no evidence of a general stronger pay-performance link following Cadbury for all firms.

\section{Conclusions}

We examine the impact of board structure on executive cash compensation for $1,880 \mathrm{UK}$ firms over 1983-2002. In contrast to previous studies, our comprehensive panel dataset should be more robust to sample selection and time period biases, and allows us to employ panel data methods that control for unobservable firm fixed effects and persistence in executive pay. We find that board size has a positive impact on the rate of increase in pay, but no evidence that it has a negative impact on the pay-performance link. We find that the proportion of non-executives has a negative impact on the rate of increase in pay and a positive impact on the pay-performance link. There is evidence of an asymmetric payperformance sensitivity, whereby when performance is poor, the pay-performance relation is much smaller than when performance is strong. However, a higher proportion of nonexecutives strengthens the link between pay and performance when performance is poor.

Our results on board size provide some support for the argument that problems of poor communication and decision-making undermine the effectiveness of large boards, at least 
with respect to the rate of increase in pay, if not the relation of pay to performance. Our evidence on the proportion of non-executives suggests that non-executive directors in the UK play an important monitoring role in shaping changes in executive pay. This lies in contrast to the argument that non-executive directors will not play an important monitoring role in the UK because of specific legal and institutional factors (Franks et al., 2001), and to previous UK studies which find that non-executives do not play an important monitoring role in terms of CEO dismissals. One possibility is that non-executive directors in the UK are more effective at certain monitoring tasks than others, and more effective for example, at setting executive pay than at dismissing poorly performing CEOs.

We find that firms that adopt the Cadbury Code's recommendation of having at least three non-executive directors subsequently experience a lower rate of increase in pay and stronger pay-performance sensitivity. This suggests that our results are less likely to be driven by endogeneity problems and that corporate governance reforms can possibly improve the effectiveness of executive pay, a conclusion similar to that reached by recent US evidence (Chhaochharia and Grinstein, 2009). However, it is noteworthy that this positive effect only applies to those firms that actually adopt the recommendation. For all firms as a whole following Cadbury, there is if anything a higher rate of increase in pay and a decrease in the relation between pay and performance.

The corporate governance reforms of recent years, both in the UK and elsewhere in the world, have argued that a higher proportion of non-executives will improve corporate governance in a number of areas, one of which is executive pay. It is argued that a higher proportion of non-executives will lead to both less excessive pay growth and a stronger link between pay and performance. Our evidence shows that this argument has well founded empirical support. Given the increased importance attached to non-executive directors in the setting of executive pay around the world, and the adoption of reforms similar to those seen in the UK, our findings are of widespread relevance. 


\section{Bibliography}

Aggarwal, R., and Samwick, A. 1999. The other side of the tradeoff: the impact of risk on executive compensation. Journal of Political Economy, 107, 65-105.

Agrawal, A. and Knoeber, C. R. 1996. Firm performance and mechanisms to control agency problems between managers and shareholders, The Journal of Financial and Quantitative Analysis, 31, 377-397.

Anderson. T., and Hsiao, C. 1982. Formulation and estimation of dynamic models using panel data. Journal of Econometrics, 18, 67-82.

Angbazo, L., and Narayanan, R. 1997. Top management compensation and the board of directors in commercial banks. European Finance Review, 1, 239-259.

Arellano, M., and Bond, S. 1991. Some tests of specification for panel data: Monte Carlo evidence and application to employment equations. The Review of Economic Studies, 58, $277-297$.

Bebchuk, L.A., and Fried, J.M. 2003. Executive compensation as an agency problem. Journal of Economic Perspectives, 17, 71-92.

Benito, A., and Conyon, M. 1999. The governance of directors' pay: Evidence from UK companies. Journal of Management \& Governance, 3, 117-136.

Bertrand, M., and Mullainathan, S. 2001. Are executives paid for luck? The ones without principals are. Quarterly Journal of Economics, 116, 901-932.

Cadbury, Sir A. 1992. Report of the Committee on the Financial Aspects of Corporate Governance. GEE: London.

Chhaochharia, V., and Grinstein, Y. 2009. CEO compensation and board structure. Journal of Finance, 64, 231-261.

Conyon, M. 1997. Corporate governance and executive compensation. International Journal of Industrial Organization, 15, 493-509.

Conyon, M., and Leech, D. 1994. Top pay, company performance and corporate governance. Oxford Bulletin of Economics \& Statistics, 56, 229-247. 
Conyon, M., and Murphy, K. 2000. The prince and the pauper? CEO pay in the United States and United Kingdom. Economic Journal, 110, 640-671.

Conyon M., and Peck S. 1998. Board control, remuneration committees, and top management compensation. Academy of Management Journal, 41, 146-157.

Core, J., Holthausen, R., and Larcker, D. 1999. Corporate governance, chief executive officer compensation and firm performance. Journal of Financial Economics, 51, 371-406.

Cosh, A., and Hughes, A. 1987. The anatomy of corporate control: Directors, shareholders and executive remuneration in giant US and UK companies. Cambridge Journal of Economics, 11, 285-313.

Cosh, A., and Hughes, A. 1997. Executive remuneration, executive dismissal and institutional shareholdings. International Journal of Industrial Organisation, 15, 469-492.

Crespi-Cladera, R. and Renneboog, L. 2003. Corporate monitoring by shareholder coalitions in the UK. Working paper, European Corporate Governance Institute.

Cyert, R., Kang, S., and Kumar, P. 2002. Corporate governance, takeovers, and top management compensation: Theory and evidence. Management Science, 48, 453-469.

Dahya, J., McConnell, J.J., and Travlos, N.G. 2002. The Cadbury Committee, corporate performance, and top management turnover. Journal of Finance, 57, 461-483.

Dahya, J., and McConnell, J.J. 2005. Outside directors and corporate board decisions. Journal of Corporate Finance, 11, 37-60.

Dahya, J., and McConnell, J.J. 2007. Board composition, corporate performance, and the Cadbury Committee recommendations. Journal of Financial and Quantitative Analysis, $42,535-564$.

Eisenberg, T., Sundgren, S., and Wells, M.T. 1998. Larger board size and decreasing firm value in small firms. Journal of Financial Economics, 48, 35-54.

Evans, R., and Evans, J. 2002. The influence of non-executive director control and rewards on CEO remuneration: Australian evidence. Working Paper, Curtin University of Technology. 
Ezzamel, M., and Watson, R. 2002. Pay comparability across and within UK boards: An empirical analysis of the pay cash awards to CEOs and other board members, Journal of Management Studies, 39, 207-232.

Fama, E., and Jensen, M.C. 1983. Separation of ownership and control. Journal of Law and Economics, 26, 301- 326.

Fernandes, N.G. 2008. Board compensation and firm performance: The role of 'independent' board members. Journal of Multinational Financial Management, 18, 30-44.

Franks, J., Mayer, C., and Renneboog, L. 2001. Who disciplines management in poorly performing companies? Journal of Financial Intermediation, 10, 209-248.

Garvey, G.T., and Milbourn, T. 2006. Asymmetric benchmarking in compensation: Executives are rewarded for good luck but not penalized for bad. Journal of Financial Economics, 82, 197-225

Girma, S., Thompson, S., and Wright, P. 2006. The impact of merger activity on executive pay in the UK. Economica, 73, 321-341.

Girma, S., Thompson, S., and Wright, P. 2007. Corporate governance reforms and executive compensation determination: Evidence from the UK. Manchester School, 75, 65-81.

Greenbury, Sir R. 1995. Directors' Remuneration: Report of a Study Group Chaired by Sir Richard Greenbury. GEE: London.

Guest, P.M. 2008. The determinants of board size and composition: Evidence from the UK. Journal of Corporate Finance, 14, 51-72.

Hallock, K.F. 1997. Reciprocally interlocking boards of directors and executive compensation. Journal of Financial and Quantitative Analysis, 32, 331-344.

Hampel, Sir R. 1998. Committee on Corporate Governance: Final Report. GEE: London.

Hermalin, B., and Weisbach, M. 1988. Endogenously chosen boards of directors and their monitoring of the CEO. American Economic Review, 88, 96-118.

Hermalin, B., and Weisbach, M. 2003. Boards of directors as an endogenously determined institution: A survey of the economic evidence. Economic Policy Review, 9, 7-26. 
Higgs, D. 2003. Review of the Role and Effectiveness of Non- Executive Directors. Department of Trade and Industry/HMSO: London.

Jensen, M.C. 1993. The modern industrial revolution, exit, and the failure of internal control systems. Journal of Finance, 48, 831-880.

Jensen, M.C., and Murphy, K. 2004. Remuneration: Where we've been, how we got to here, what are the problems, and how to fix them. Working Paper, European Corporate Governance Institute.

Kren, L., and Kerr, J.L. 1997. The effects of outside directors and board shareholdings on the relation between chief executive compensation and firm performance. Accounting and Business Research, 27, 297-309.

Linck, J., Netter, J., and Yang, T. 2008. The determinants of board structure. Journal of Financial Economics, 87, 308-328.

Lipton, M., and Lorsch, J.W. 1992, A modest proposal for improved corporate governance. Business Lawyer, 48, 59- 77.

Main, B. 1991. Top executive pay and performance. Managerial and Decision Economics, $12,219-229$.

Main, B., Bruce, A., and Buck, T. 1996. Total board remuneration and company performance. Economic Journal, 106, 1627-1644.

Main, B., and Crystal, G.S. 1988. CEO compensation as tournament and social comparison: A tale of two theories. Administrative Science Quarterly, 33, 257-274.

Main, B., and Johnston, J. 1993. Remuneration committees and corporate governance. Accounting and Business Research, 23, 351-362.

Mangel, R., and Singh, H. 1993. Ownership structure, board relationships and CEO compensation in large US corporations. Accounting and Business Research, 23, 339-350.

Murphy, K. 1999. Executive compensation. In O. Ashenfelter and D. Card (eds.), Handbook of Labor Economics. North Holland: Amsterdam.

Nickell, S. 1981. Biases in dynamic models with fixed effects. Econometrica, 49, 1417-1426. 
Ozkan, N. 2007. Do corporate governance mechanisms influence CEO compensation? An empirical investigation of UK companies. Journal of Multinational Financial Management. 17, 349-364.

Schaefer, S. 1998. The dependence of pay-performance sensitivity on the size of the firm. Review of Economics and Statistics, 80, 436-443.

Short, H. and Keasey, K. 1999. Managerial ownership and the performance of firms: Evidence from the UK. Journal of Corporate Finance, 5, 79-101.

Singh, H., and Harianto, F. 1989. Management board relationships, takeover risk, and the adoption of golden parachutes. Academy of Management Journal, 32, 7-24.

Vafeas, N., and Theodorou, E. 1998. The relationship between board structure and firm performance in the UK. British Accounting Review, 30, 383-407.

Yermack, D. 1996. Higher market valuation of companies with a small board of directors. Journal of Financial Economics, 40, 185-221.

Zajac, E.J., and Westphal, J.D. 1994. The costs and benefits of managerial incentives and monitoring in large US corporations: When is more not better? Strategic Management Journal, 15, 121-142.

Wintoki, J. 2007. Endogeneity and the dynamics of corporate governance. Working paper, University of Georgia. 
Table 1. Summary of studies on the effect of board structure on executive pay

\begin{tabular}{lccccccc}
\hline Study & Year & $\begin{array}{c}\text { Time } \\
\text { period }\end{array}$ & Country & $\begin{array}{c}\text { Sample } \\
\text { size }\end{array}$ & Method & \multicolumn{2}{c}{ Board structure } \\
\cline { 5 - 7 } & & & & & & $\begin{array}{c}\text { Board } \\
\text { size }\end{array}$ & $\begin{array}{c}\text { \%Non- } \\
\text { executives }\end{array}$ \\
\hline Panel A: Pay levels & & & & & & & \\
Main & 1991 & 1985 & UK & 241 & OLS & $+*$ & $+*$ \\
Main \& Johnston & 1993 & 1990 & UK & 220 & OLS & n.a. & $+*$ \\
Mangel \& Singh & 1993 & 1988 & US & 79 & OLS & n.a. & + \\
Angbazo \& & 1997 & 1989 & US & 97 & OLS & + & + \\
Narayanan & & & & & & & + \\
Cosh \& Hughes & 1997 & $1989-94$ & UK & 371 & OLS & n.a. & $+*$ \\
Hallock & 1997 & 1992 & US & 773 & OLS & $+*$ & n.a. \\
Kren \& Kerr & 1997 & $1987 / 1989$ & US & 268 & OLS & n.a. & + \\
Core et al. & 1999 & $1982-84$ & US & 205 & OLS & $+*$ & n.a. \\
Cyert et al. & 2002 & 1993 & US & 1,648 & OLS & - & $+*$ \\
Evans \& Evans & 2002 & 1997 & Australia & 350 & OLS & n.a. & + \\
Fernandes & 2008 & 2004 & Portugal & 58 & OLS & n.a. & $+*$ \\
Ozkan & 2007 & 2004 & UK & 414 & OLS & $+*$ & $+*$ \\
\hline Panel B: Pay-performance sensitivity & & & & & \\
Yermack & 1996 & $1984-91$ & US & 452 & OLS & $-*$ & n.a. \\
Kren \& Kerr & 1997 & $1987 / 1989$ & US & 268 & OLS & n.a. & $-*$ \\
Conyon \& Peck & 1998 & $1991-94$ & UK & 94 & Fixed & n.a. & $+*$ \\
& & & & & effects & & \\
\hline This & & & & & \\
\end{tabular}

This table reports the main findings of previous studies that examine the impact of board structure on executive pay levels and pay-performance sensitivity. ${ }^{*}$ denotes statistical significance at the $10 \%$ level or better. 
Table 2. Sample description

\begin{tabular}{|c|c|c|c|c|c|}
\hline \multicolumn{3}{|c|}{ Number of data observations per year } & \multicolumn{3}{|c|}{ Number of yearly data observations per firm } \\
\hline Year & $\begin{array}{c}\text { Data } \\
\text { observations }\end{array}$ & $\begin{array}{l}\text { Percent } \\
\text { of total }\end{array}$ & $\begin{array}{l}\text { Number of yearly } \\
\text { data observations }\end{array}$ & $\begin{array}{l}\text { Number of } \\
\text { firms }\end{array}$ & $\begin{array}{l}\text { Percent } \\
\text { of total }\end{array}$ \\
\hline 1983 & 71 & 0.5 & 1 & 221 & 11.8 \\
\hline 1984 & 166 & 1.2 & 2 & 165 & 8.8 \\
\hline 1985 & 240 & 1.8 & 3 & 196 & 10.4 \\
\hline 1986 & 281 & 2.1 & 4 & 170 & 9.0 \\
\hline 1987 & 318 & 2.4 & 5 & 110 & 5.9 \\
\hline 1988 & 404 & 3.0 & 6 & 99 & 5.3 \\
\hline 1989 & 543 & 4.0 & 7 & 114 & 6.1 \\
\hline 1990 & 623 & 4.6 & 8 & 107 & 5.7 \\
\hline 1991 & 675 & 5.0 & 9 & 93 & 5.0 \\
\hline 1992 & 761 & 5.6 & 10 & 101 & 5.4 \\
\hline 1993 & 860 & 6.4 & 11 & 90 & 4.8 \\
\hline 1994 & 869 & 6.4 & 12 & 85 & 4.5 \\
\hline 1995 & 950 & 7.0 & 13 & 73 & 3.9 \\
\hline 1996 & 1014 & 7.5 & 14 & 81 & 4.3 \\
\hline 1997 & 1026 & 7.6 & 15 & 52 & 2.8 \\
\hline 1998 & 1009 & 7.5 & 16 & 37 & 2.0 \\
\hline 1999 & 959 & 7.1 & 17 & 26 & 1.4 \\
\hline 2000 & 939 & 7.0 & 18 & 30 & 1.6 \\
\hline 2001 & 917 & 6.8 & 19 & 19 & 1.0 \\
\hline 2002 & 867 & 6.4 & 20 & 11 & 0.6 \\
\hline Total & 13,492 & 100 & Total & 1,880 & 100 \\
\hline
\end{tabular}

This table displays the sample in terms of the number of data observations per year and the number of yearly data observations per firm. We start with all UK firms in the Datastream database from 1983 to 2002 . We restrict the sample to those firms that have information on all the variables described in Table 3 below, for a sample year and for at least two preceding years. We further exclude all financial and real estate firms (Datastream Level 4 Industry groupings 80-89 inclusive). 
Table 3. Descriptive statistics for variables used in the analysis

\begin{tabular}{lcccc}
\hline Variable & Number & Mean & Median & Standard deviation \\
\hline Pay & 13,492 & 5.38 & 5.31 & 0.74 \\
Size & 13,492 & 11.72 & 11.60 & 2.00 \\
Return & 13,492 & 0.01 & 0.05 & 0.48 \\
Standard deviation & 13,492 & 0.11 & 0.10 & 0.07 \\
\%Non-executives & 13,492 & 0.43 & 0.43 & 0.15 \\
Board size & 13,492 & 1.96 & 1.95 & 0.34 \\
\hline
\end{tabular}

This table reports summary statistics for the sample. Pay is the logarithm of the cash compensation (salary plus bonus plus the cash equivalents of any perquisites but excluding pension contributions) of the highest paid director. Size is the logarithm of company sales adjusted for inflation. Return is the logarithm of the buy and hold share return over the 12 months preceding the financial year end. Standard deviation is the standard deviation of monthly share returns over the 12 months preceding the financial year end. \%Non-executives is the number of non-executive directors divided by the total number of directors. Board size is the logarithm of the total number of directors on the board. 
Table 4. The impact of board structure on executive pay levels and pay-performance sensitivity

\begin{tabular}{|c|c|c|c|}
\hline & $(1)$ & $(2)$ & (3) \\
\hline \multirow[t]{2}{*}{ Intercept } & $0.05^{\mathrm{b}}$ & $0.05^{\mathrm{b}}$ & 0.05 \\
\hline & $(2.09)$ & $(2.08)$ & $(1.33)$ \\
\hline \multirow[t]{2}{*}{$\Delta$ Pay $_{\text {it- } 1}$} & $0.30^{\mathrm{a}}$ & $0.30^{\mathrm{a}}$ & $0.30^{\mathrm{a}}$ \\
\hline & $(15.56)$ & $(15.52)$ & $(15.40)$ \\
\hline \multirow[t]{2}{*}{$\Delta$ Size $_{\text {it }}$} & $0.14^{\mathrm{a}}$ & $0.14^{\mathrm{a}}$ & $0.14^{\mathrm{a}}$ \\
\hline & $(21.48)$ & $(21.54)$ & $(21.82)$ \\
\hline \multirow[t]{2}{*}{$\Delta$ Return $_{\text {it }}$} & $0.05^{\mathrm{a}}$ & -0.05 & -0.01 \\
\hline & $(7.75)$ & $-(1.33)$ & $-(0.29)$ \\
\hline \multirow[t]{2}{*}{$\Delta$ Standard deviation $_{\text {it }}$} & $-0.24^{\mathrm{a}}$ & $-0.24^{\mathrm{a}}$ & $-0.20^{\mathrm{a}}$ \\
\hline & $-(4.40)$ & $-(4.25)$ & $-(3.58)$ \\
\hline \multirow[t]{2}{*}{$\Delta \%$ Non-executives ${ }_{\text {it- } 1}$} & $-0.12^{a}$ & $-0.13^{a}$ & $-0.12^{a}$ \\
\hline & $-(3.91)$ & $-(3.93)$ & $-(3.87)$ \\
\hline \multirow[t]{2}{*}{$\Delta$ Board size $_{\mathrm{it}-1}$} & $0.07^{\mathrm{a}}$ & $0.07^{\mathrm{a}}$ & $0.07^{\mathrm{a}}$ \\
\hline & $(3.68)$ & $(3.62)$ & $(3.53)$ \\
\hline \multirow[t]{2}{*}{$\Delta \%$ Non-executives $_{\mathrm{it}-1} *$ Return $_{\mathrm{it}}$} & & $0.09^{a}$ & $0.10^{\mathrm{a}}$ \\
\hline & & $(2.61)$ & $(2.91)$ \\
\hline \multirow[t]{2}{*}{$\Delta$ Board size $_{\text {it- } 1} *$ Return $_{\text {it }}$} & & $0.03^{c}$ & -0.01 \\
\hline & & $(1.68)$ & $-(0.38)$ \\
\hline \multirow[t]{2}{*}{$\Delta$ Standard deviation $_{\text {it }} *$ Return $_{\mathrm{it}}$} & & & $-0.31^{\mathrm{a}}$ \\
\hline & & & $-(4.53)$ \\
\hline \multirow[t]{2}{*}{$\Delta$ Size $_{\text {it }} *$ Return $_{\text {it }}$} & & & $0.01^{\mathrm{b}}$ \\
\hline & & & $(2.41)$ \\
\hline Year dummies & Yes & Yes & Yes \\
\hline Sargan ( $p$-value) & 0.4558 & 0.4601 & 0.4388 \\
\hline Serial correlation ( $p$-value) & 0.1640 & 0.1506 & 0.1394 \\
\hline No. of observations & 13,492 & 13,492 & 13,492 \\
\hline
\end{tabular}

This table reports regressions of executive pay on prior pay, board structure and various firm characteristics. The model is estimated using the Arrellano and Bond (1991) generalised method of moments procedure. This procedure uses first differences of the dependent and independent variables, and instruments the first difference of prior pay using levels of all variables dated it-2 and earlier. Variables are as defined in Table 3. The Sargan statistic tests for over-identifying restrictions, and is asymptotically distributed as $\chi^{2}$ under the null hypothesis of valid instruments. The serial correlation statistic tests the absence of second-order correlation in the residuals, and is asymptotically distributed as $\mathrm{N}(0,1)$ under the null hypothesis of no serial correlation. $P$-values are provided in parentheses. ${ }^{\mathrm{a}},{ }^{\mathrm{b}}$ and ${ }^{\mathrm{c}}$ denote significance at the 1,5 , and 10 percent level, respectively. 
Table 5. The impact of board structure on asymmetric pay-performance sensitivity

\begin{tabular}{|c|c|c|c|}
\hline & $(1)$ & $(2)$ & $(3)$ \\
\hline \multirow[t]{2}{*}{ Intercept } & $0.68^{c}$ & 0.05 & $0.67^{c}$ \\
\hline & $(1.88)$ & $(1.33)$ & $(1.89)$ \\
\hline \multirow[t]{2}{*}{$\Delta$ Pay $_{\text {it-1 }}$} & $0.31^{\mathrm{a}}$ & $0.30^{\mathrm{a}}$ & $0.30^{\mathrm{a}}$ \\
\hline & (15.73) & (15.53) & $(15.34)$ \\
\hline \multirow[t]{2}{*}{$\Delta$ Size $_{\text {it }}$} & $0.14^{\mathrm{a}}$ & $0.14^{\mathrm{a}}$ & $0.14^{\mathrm{a}}$ \\
\hline & $(22.27)$ & $(21.47)$ & $(20.42)$ \\
\hline \multirow[t]{2}{*}{$\Delta$ Return negative $_{\text {it }}$} & $0.03^{\mathrm{b}}$ & -0.03 & -0.05 \\
\hline & $(2.41)$ & $-(0.49)$ & $-(0.63)$ \\
\hline \multirow[t]{2}{*}{$\Delta$ Return positive $_{i t}$} & $0.07^{\mathrm{a}}$ & -0.06 & 0.04 \\
\hline & $(5.87)$ & $-(0.89)$ & $(0.42)$ \\
\hline \multirow{2}{*}{$\Delta$ Standard deviation $_{\text {it }}$} & $-0.27^{\mathrm{a}}$ & $-0.25^{\mathrm{a}}$ & $-0.18^{b}$ \\
\hline & $-(4.72)$ & $-(4.45)$ & $-(2.32)$ \\
\hline \multirow[t]{2}{*}{$\Delta \%$ Non-executives ${ }_{i t-1}$} & & $-0.10^{b}$ & $-0.10^{\mathrm{a}}$ \\
\hline & & $-(2.50)$ & $-(2.60)$ \\
\hline \multirow[t]{2}{*}{$\Delta$ Board size $_{\mathrm{it}-1}$} & & $0.06^{\mathrm{a}}$ & $0.06^{\mathrm{b}}$ \\
\hline & & $(2.59)$ & $(2.53)$ \\
\hline \multirow{2}{*}{$\Delta \%$ Non-executives $_{\text {it-1 }} *$ Return negative $_{\text {it }}$} & & $0.16^{\mathrm{b}}$ & $0.16^{b}$ \\
\hline & & $(2.56)$ & $(2.50)$ \\
\hline \multirow[t]{2}{*}{$\Delta \%$ Non-executives $_{\text {it- } 1} *$ Return positive $_{\text {it }}$} & & 0.02 & 0.04 \\
\hline & & $(0.26)$ & $(0.63)$ \\
\hline \multirow[t]{2}{*}{$\Delta$ Board size $_{\text {it-1 }} *$ Return negative $_{\text {it }}$} & & 0.00 & -0.03 \\
\hline & & $-(0.14)$ & $-(0.95)$ \\
\hline \multirow[t]{2}{*}{$\Delta$ Board size $_{\text {it-1 }} *$ Return positive $_{\text {it }}$} & & $0.06^{\mathrm{c}}$ & 0.02 \\
\hline & & $(1.95)$ & $(0.61)$ \\
\hline \multirow[t]{2}{*}{$\Delta$ Standard deviation $_{\text {it }} *$ Return negative $_{\text {it }}$} & & & $-0.24^{\mathrm{c}}$ \\
\hline & & & $-(1.83)$ \\
\hline \multirow[t]{2}{*}{$\Delta$ Standard deviation $_{\text {it }} *$ Return positive $_{\text {it }}$} & & & $-0.36^{\mathrm{a}}$ \\
\hline & & & $-(2.73)$ \\
\hline \multirow[t]{2}{*}{$\Delta$ Size $_{\text {it }} *$ Return negative $_{\text {it }}$} & & & $0.01^{\mathrm{c}}$ \\
\hline & & & $(1.89)$ \\
\hline \multirow[t]{2}{*}{$\Delta$ Size $_{\text {it }} *$ Return positive $_{\text {it }}$} & & & 0.00 \\
\hline & & & $(0.35)$ \\
\hline Year dummies & Yes & Yes & Yes \\
\hline Sargan ( $p$-value) & 0.4727 & 0.4213 & 0.3999 \\
\hline Serial correlation ( $p$-value) & 0.1629 & 0.1483 & 0.1469 \\
\hline No. of observations & 13,492 & 13,492 & 13,492 \\
\hline
\end{tabular}

This table reports regressions of executive pay on prior pay, board structure and various firm characteristics. The model is estimated using the Arrellano and Bond (1991) generalised method of moments procedure. This procedure uses first differences of the dependent and independent variables, and instruments the first difference of prior pay using levels of all variables dated it-2 and earlier. Return negative is equal to the logarithm of the buy and hold share return over the 12 months preceding the financial year end if the return is negative, otherwise it is set equal to zero. Return positive is equal to the logarithm of the buy and hold share return over the 12 months preceding the financial year end if the return is positive, otherwise it is set equal to zero. Other variables are as defined in Table 3. The Sargan statistic tests for over-identifying restrictions, and is asymptotically distributed as $\chi_{2}$ under the null hypothesis of valid instruments. The serial correlation statistic tests the absence of second-order correlation in the residuals, and is asymptotically distributed as $N(0,1)$ under the null hypothesis of no serial correlation. $P$-values are provided in parentheses. ${ }^{\mathrm{a}},{ }^{\mathrm{b}}$ and ${ }^{\mathrm{c}}$ denote significance at the 1,5 , and 10 percent level, respectively. 
Table 6. Classification of firms according to whether or not they adopt Cadbury

\begin{tabular}{|c|c|c|c|c|c|c|c|c|c|c|c|c|}
\hline \multirow{6}{*}{$\begin{array}{l}\text { Pre-Cadbury } \\
\text { compliance } \\
\text { Post-Cadbury } \\
\text { compliance }\end{array}$} & \multicolumn{4}{|c|}{ Always } & \multicolumn{4}{|c|}{ Never } & \multicolumn{4}{|c|}{ Some } \\
\hline & \multicolumn{4}{|c|}{260} & \multicolumn{4}{|c|}{351} & \multicolumn{4}{|c|}{435} \\
\hline & Always & Never & \multicolumn{2}{|c|}{ Some } & Always & Never & \multicolumn{2}{|c|}{ Some } & Always & Never & \multicolumn{2}{|c|}{ Some } \\
\hline & 211 & 2 & \multicolumn{2}{|c|}{47} & 38 & 118 & \multicolumn{2}{|c|}{195} & 184 & 38 & \multicolumn{2}{|c|}{213} \\
\hline & & & $\begin{array}{l}\text { Once } \\
\text { comply- } \\
\text { always } \\
\text { comply }\end{array}$ & $\begin{array}{l}\text { Comply- } \\
\text { then no } \\
\text { comply }\end{array}$ & & & $\begin{array}{l}\text { Once } \\
\text { comply- } \\
\text { always } \\
\text { comply }\end{array}$ & $\begin{array}{l}\text { Comply- } \\
\text { then no } \\
\text { comply }\end{array}$ & & & $\begin{array}{c}\text { Once comply- } \\
\text { always } \\
\text { comply }\end{array}$ & $\begin{array}{l}\text { Comply- } \\
\text { then no } \\
\text { comply }\end{array}$ \\
\hline & & & 7 & 40 & & & 108 & 87 & & & 72 & 141 \\
\hline Group & 1 & 2 & 3 & 4 & 5 & 6 & 7 & 8 & 9 & 10 & 11 & 12 \\
\hline No. of firms & 211 & 2 & 7 & 40 & 38 & 118 & 108 & 87 & 184 & 38 & 72 & 141 \\
\hline $\begin{array}{l}\text { No. of } \\
\text { observations }\end{array}$ & 2,307 & 13 & 68 & 484 & 319 & 816 & 1,049 & 835 & 2,056 & 350 & 834 & 1,659 \\
\hline Adopters? & No & No & No & No & Yes & No & Yes & No & Yes & No & Yes & No \\
\hline
\end{tabular}

This table analyses the sub-sample of 1,046 sample firms which have firm year observations both before and after the Cadbury Code in 30/06/1993. It firstly splits this subsample according to whether, before Cadbury (30/06/1993), the firm always has, never has, or sometimes has three non-executive directors. It secondly splits these sub samples according to whether after Cadbury the firm always has, never has, or sometimes has three non-executive directors. If the latter, a further classification is made according to whether, once the firm has three non-executive directors, it always maintains at least three non-executive directors or whether it then reverts to less than three. The sample of 1,046 firms can be split into 12 separate groups on these criteria. In the final row of the table, we classify the firms into two groups according to whether they are adopters (402 firms), or not (644 firms). 


\begin{tabular}{|c|c|c|c|}
\hline & $\begin{array}{c}\text { (1) } \\
\text { Adopters only }\end{array}$ & $\begin{array}{c}(2) \\
\text { All firms }\end{array}$ & $\begin{array}{c}\text { (3) } \\
\text { All firms }\end{array}$ \\
\hline \multirow[t]{2}{*}{ Intercept } & 0.03 & 0.00 & 0.03 \\
\hline & $(0.40)$ & $-(0.16)$ & $(0.57)$ \\
\hline \multirow[t]{2}{*}{$\Delta$ Pay $_{\text {it }-1}$} & $0.26^{\mathrm{a}}$ & $0.28^{a}$ & $0.29^{\mathrm{a}}$ \\
\hline & $(9.00)$ & $(13.66)$ & (14.09) \\
\hline \multirow[t]{2}{*}{$\Delta$ Size $_{\text {it }}$} & $0.16^{\mathrm{a}}$ & $0.17^{\mathrm{a}}$ & $0.17^{\mathrm{a}}$ \\
\hline & $(11.66)$ & $(19.39)$ & $(19.63)$ \\
\hline \multirow[t]{2}{*}{$\Delta$ Return $_{\text {it }}$} & $0.04^{\mathrm{a}}$ & $0.08^{a}$ & $0.07^{\mathrm{a}}$ \\
\hline & $(2.57)$ & $(5.24)$ & $(5.38)$ \\
\hline \multirow[t]{2}{*}{$\Delta$ Standard deviation $_{\text {it }}$} & $-0.51^{a}$ & $-0.31^{\mathrm{a}}$ & $-0.32^{a}$ \\
\hline & $-(4.90)$ & $-(4.87)$ & $-(4.98)$ \\
\hline \multirow[t]{2}{*}{ Adopters post-Cadbury it } & -0.01 & $-0.01^{c}$ & \\
\hline & $-(1.26)$ & $-(1.73)$ & \\
\hline \multirow[t]{2}{*}{ Adopters post-Cadbury $_{\text {it }} * \Delta$ Return $_{\text {it }}$} & $0.04^{\mathrm{c}}$ & $0.06^{\mathrm{b}}$ & \\
\hline & $(1.70)$ & $(2.52)$ & \\
\hline \multirow[t]{2}{*}{ Adopters $_{i}$} & & 0.01 & \\
\hline & & $(1.29)$ & \\
\hline \multirow[t]{2}{*}{ Adopters $_{\mathrm{i}} * \Delta$ Return $_{\mathrm{it}}$} & & -0.02 & \\
\hline & & $-(1.22)$ & \\
\hline \multirow[t]{2}{*}{ Post-Cadbury it } & & 0.04 & 0.03 \\
\hline & & $(1.63)$ & $(1.40)$ \\
\hline \multirow[t]{2}{*}{ Post-Cadbury it $_{\text {it }} * \Delta$ Return $_{\text {it }}$} & & $-0.04^{\mathrm{a}}$ & $-0.03^{c}$ \\
\hline & & $-(2.60)$ & $-(1.70)$ \\
\hline Year dummies & Yes & Yes & Yes \\
\hline Sargan ( $p$-value) & 0.2242 & 0.1787 & 0.2267 \\
\hline Serial correlation ( $p$-value) & 0.2741 & 0.2854 & 0.2502 \\
\hline No. of observations & 4,258 & 10,790 & 10,790 \\
\hline
\end{tabular}

This table reports regressions of executive pay on whether sample firms adopted the Cadbury recommendation of having at least three non-executive directors. The model is estimated using the Arrellano and Bond (1991) generalised method of moments procedure. This procedure uses first differences of the dependent and independent variables, and instruments the first difference of prior pay using levels of all variables dated $i t-2$ and earlier. Post-Cadbury is a dummy variable set equal to one for all financial years after Cadbury (30/06/1993), zero for all years prior. Adopters is a dummy variable set equal to one for those firms classified as adopters in Table 6, zero otherwise. Adopters post-Cadbury is a dummy variable set equal to one for all years after which Adopters have adopted Cadbury, zero for all years prior to this. Other variables are as defined in Table 3 above. The sample employed in Column (1) is the 402 sample firms which have firm year observations both before and after the Cadbury Code (30/06/1993), and are identified as adopters in Table 6. The samples employed in Columns (2) and (3) are all the 1,046 sample firms for which we have firm year observations both before and after the Cadbury Code (30/06/1993). The Sargan statistic tests for over-identifying restrictions, and is asymptotically distributed as $\chi_{2}$ under the null hypothesis of valid instruments. The serial correlation statistic tests the absence of second-order correlation in the residuals, and is asymptotically distributed as $\mathrm{N}(0,1)$ under the null hypothesis of no serial correlation. $P$-values are provided in parentheses. ${ }^{\mathrm{a}},{ }^{\mathrm{b}}$ and ${ }^{\mathrm{c}}$ denote significance at the 1,5 , and 10 percent level, respectively. 


\section{Notes}

1 Previous studies have attempted to overcome simultaneous endogeneity by employing instrumental variable techniques. However, such regressions require the identification of strictly exogenous instrumental variables which Wintoki (2007) argues is almost impossible in a corporate governance setting.

2 The majority of empirical studies, reviewed by Hermalin and Weisbach (2003), document a negative association between board size and firm performance.

3 These include the requirements that all firms must have a majority of independent directors and that all board committees consist of independent directors only.

4 Although the proportion of non-executives increased following Cadbury (Dahya et al., 2002; and Guest, 2008), it is still relatively low and non-executive director independence is still weak due to an appointment process which is too informal (Higgs, 2003).

5 However, there is evidence that firms which increase the number of non-executive directors following the Cadbury recommendations experience better monitoring in terms of CEO turnover (Dahya et al., 2002) and better overall performance (Dahya and McConnell, 2007).

6 For more details on the establishment of the Cadbury Committee, see Dahya et al. (2002).

7 Another key recommendation of Cadbury was that the CEO and Chairman should be separate directors. Conyon and Leech (1994), Conyon (1997), and Benito and Conyon (1999) find no evidence that the CEO-Chairman separation has a significant effect on executive pay. 8 Although compliance with the Greenbury (1995) disclosure recommendation was initially on a comply or explain basis, in 2002 it was made a statutory requirement.

9 Due to data availability on Datastream, we are only able to classify directors as executive or non-executive, and not in terms of finer classifications of independence. This approach is similar to most previous large sample studies for both the US and UK.

10 Bertrand and Mullainathan (2001) show that pay is linked not just to firm but also to industry performance, which they refer to as 'lucky' pay, and that strong corporate 
governance reduces this link. We examine this by including the average industry share return as well as the firm return. The results, not tabulated, show that the coefficient for the industry return is positive but statistically insignificant, whilst the firm return coefficient is still significantly positive. Therefore we find no evidence that UK executive pay is impacted by 'luck'. We further find no evidence that the link between pay and industry return is impacted by the proportion of non-executives or board size.

11 For example, Guest (2008) shows that although Cadbury has a significant positive impact on the proportion of non-executives, adoption of the Cadbury recommendation to employ at least three non-executives is associated with many of the usual determinants of non-executive representation. 